\title{
Current Status of Folic Acid Supplementation on Colorectal Cancer Prevention
}

\author{
Young-In Kim ${ }^{1,2,3,4}$
}

Published online: 14 January 2016

(C) Springer International Publishing AG 2016

\begin{abstract}
Folate and its synthetic form, folic acid, play an important role in one-carbon transfer reactions involved in DNA synthesis and methylation, aberrations of which contribute to the development of colorectal cancer. Indeed, a portfolio of epidemiologic evidence suggests an inverse association between folate status and colorectal cancer risk. However, animal studies and clinical trials collectively suggest a dual modulatory effect of folic acid supplementation on colorectal cancer risk depending on the stage of cell transformation at the time of intervention. Folic acid supplementation may prevent neoplastic initiation in the colorectum but it may promote the progression of established precancerous lesions. Concerns have been raised over whether or not the significantly increased intake and blood levels of folate resulting from folic acid fortification and prevalent supplemental folic acid use would increase the incidence and mortality of cancer in North America. Recent epidemiologic studies, however, have reported a decreasing trend of colorectal cancer incidence postfortification in the USA and have not demonstrated a colorectal cancer-promoting effect of folic acid supplementation.
\end{abstract}

This article is part of the Topical Collection on Cancer Chemoprevention

Young-In Kim

youngin.kim@utoronto.ca

1 Department of Medicine, University of Toronto, Toronto, Ontario, Canada

2 Department of Nutritional Sciences, University of Toronto, Toronto, Ontario, Canada

3 Keenan Research Center for Biomedical Science of St. Michael's Hospital, Toronto, Ontario, Canada

4 Division of Gastroenterology, Department of Medicine, St. Michael's Hospital, 16CC-038, 30 Bond Street, M5B 1W8 Toronto, Ontario, Canada
Nevertheless, the effect of the dramatically increased folate status in North America on cancer incidence and mortality requires continued careful monitoring, given serious pubic health ramifications. At present, based on the lack of compelling supportive evidence and on the potential tumorpromoting effect, folic acid supplementation should not be recommended as a chemopreventive measure against colorectal cancer or any other cancers. Whether or not folic acid supplementation can prevent the development of colorectal cancer remains a highly controversial and complex topic at present.

Keywords Folate/folic acid · Colorectal cancer · Prevention . Carcinogenesis $\cdot$ Epigenetics

\section{Introduction}

The role of folate in cancer development and progression is highly controversial [1-7]. Traditionally, the role of folate in cancer has been studied in the context of antifolate and cancer chemotherapy. Folate mediates the transfer of one-carbon moieties involved in the de novo biosynthesis of purines and thymidylate, thereby playing an important role in DNA synthesis and replication [2, 8]. Folate deficiency induces ineffective DNA synthesis, and in rapidly replicating cells, such as neoplastic cells, this will result in inhibition of tumor growth $[1,2]$. As such, interruption of folate metabolism has been the basis for cancer chemotherapy using antifolate agents and 5fluorouracil $[1,2]$. In experimental models, folate deficiency has been shown to suppress progression and induce regression of pre-existing neoplasms [9-11]. In the 1940s, folic acid (the synthetic form of folate) supplementation was shown to accelerate the progression of leukemia in children with acute leukemia [12] and to cause rapid hematologic and clinical relapse 
in patients with chronic myeloid leukemia [13], the critical discovery that led to the development of antifolate-based chemotherapy [14]. These observations suggest that folate deficiency and supplementation have an inhibitory and promoting effect on established neoplasms, respectively.

In contrast, folate status appears to have an opposite effect in normal tissues. A large body of experimental, epidemiologic, and clinical studies suggests that folate deficiency in normal tissues predisposes them to neoplastic transformation while folic acid supplementation suppresses neoplastic initiation in normal tissues $[1,2]$. Epidemiologic studies have generally suggested an inverse association between folate status and the risk of several human malignancies including cancer of the colorectum, oropharynx, esophagus, stomach, pancreas, breast, cervix, ovary, and lungs and neuroblastoma and leukemia $[1,2,15,16]$. However, the precise nature and magnitude of this purported inverse relationship have not been unequivocally established $[1,2,15,16]$.

Folate has generally been regarded as safe [17] and beneficial for disease prevention [18]. Because of this perceived safety profile and possible chemopreventive effect, folic acid has been embraced as a potentially safe and effective chemopreventive agent against colorectal cancer. However, serious public health concerns have been raised regarding a potential cancer-promoting effect of significantly increased folate and folic acid intake and blood levels in North America, owing in part to mandatory folic acid fortification and widespread supplemental use of folic acid [16, 19, 20]. Given this consideration, the objectives of this report are to review the currently available evidence for the purported association between folate status and colorectal cancer risk and to highlight potential benefits and risks of folic acid chemoprevention of colorectal cancer.

\section{Folate and Folic Acid}

Folate is a B vitamin (vitamin $\mathrm{B}_{9}$ ) that is present naturally in foods such as green leafy vegetables, asparagus, broccoli, Brussels sprouts, citrus fruit, legumes, dry cereals, whole grain, yeast, lima beans, liver, and other organ meats [21]. Folate is the generic term encompassing all compounds with similar chemical structures, biological function, and nutritional properties [8]. Folate consists of three moieties including a pteridine ring with varying state of reduction attached to paraaminobenzoic acid with one or more glutamate residues attached via $\gamma$-peptide bonds [8]. Naturally occurring folates are highly unstable and easily oxidized under low $\mathrm{pH}$ and hence rapidly lose their activity in foods through food harvesting, storage, processing, and preparation [21]. Folate bioavailability varies widely depending on the food source and food preparation method [21].
Folic acid is the fully oxidized monoglutamyl form of folate and hence is highly stable and bioavailable compared with naturally occurring folates [21]. As a result, folic acid is used as supplements and fortificants in foods [8]. Folic acid must be reduced to dihydrofolate and then to tetrahydrofolate by dihydrofolate reductase followed by methylation to 5-methyltetrahydrofolate (predominant circulating form of folate), in the liver and to a lesser degree in the small intestine [22]. The capacity of this conversion is limited, and thus, folic acid intake can readily saturate this capacity, resulting in the appearance of unaltered or unmetabolized folic acid (UMFA) in circulation [23]. As little as $280 \mu \mathrm{g}$ of folic acid has been shown to overwhelm the capacity of dihydrofolate reductase and result in the detection of plasma UMFA [23, 24].

Mammals are generally unable to synthesize folate and therefore must obtain folate from dietary or supplemental sources [8]. One exception is the de novo synthesis of folate by intestinal microflora, which can be absorbed across the large intestine and incorporated into the host's tissues [25-28]. The recommended dietary intake of folate in North American adult men and women is $400 \mu \mathrm{g}$ dietary folate equivalents per day, which varies according to age, pregnancy, and lactation [21].

Folate plays an important function in DNA synthesis, stability and integrity, and repair in its role in mediating the transfer of one-carbon units involved in de novo purine and thymidylate synthesis $[2,8]$. Furthermore, folate, in the form of 5-methyltetrahydrofolate, mediates the transfer of onecarbon group involved in remethylation of homocysteine to methionine, thereby ensuring the provision of $S$ adenosylmethionine, the primary methyl group donor for most biological methylation reactions, including that of DNA $[2,8]$.

Folate is essential for proper cell division and normal growth and development and hence plays a crucial role in human health and disease [20, 29]. Folate deficiency has been linked to macrocytic anemia, congenital defects including neural tube defects, adverse pregnancy and birth outcomes, coronary heart disease and stroke, cognitive dysfunction, and certain cancers [20, 21, 29]. In contrast to observational epidemiologic studies, which have generally supported the inverse association between folate status and cardiovascular disease risk, the overwhelming majority of randomized clinical trials and their meta-analyses or pooled analyses have shown a null effect of folic acid supplementation on coronary heart disease [30, 31]. However, clinical trials have shown that folic acid supplementation can reduce the risk of stroke [32, 33]. Folic acid supplementation appears to delay age-related cognitive decline [34] and prevent and/or slow the rate of brain atrophy [35, 36], although other studies have not confirmed this protective effect $[37,38]$. 


\section{Folic Acid Fortification and Supplementation}

Mandatory folic acid fortification was implemented in North America in 1998 based on a convincing body of evidence for a protective effect of periconceptional folic acid supplementation on neural tube defects [39, 40]. Mandatory folic acid fortification appears to have met its primary objectives as evidenced by significantly increased dietary intakes and blood measurements of folate/folic acid [41, 42, 43•] and significantly reduced neural tube defect rates by $15-50 \%$ postfortification [44-46]. The supplemental use of folic acid is prevalent in North America with some population-based surveys reporting that up to $40 \%$ of the North American population are taking folic acid supplement [47, 48]. Folic acid supplementation in the range of $0.4-1.0 \mathrm{mg} /$ day is recommended to women of reproductive age to prevent neural tube defects [49]. Vitamins are also widely used among patients newly diagnosed with cancer and cancer survivors, up to $80 \%$ in some studies [50, 51]. In particular, $\sim 40 \%$ of colorectal cancer patients and survivors are known to use multivitamins $[52,53]$. One study reported that 31 and $1.5 \%$ of colorectal cancer patients used multivitamins and single-supplement folic acid, respectively, before diagnosis, which increased to 43 and $7 \%$, respectively, 2 years after diagnosis [54]. A more recent study reported a much higher use before and after colorectal cancer diagnosis (35 and $55 \%$, respectively) [55].

\section{Current Folate Status in North America}

In the most recent report using the National Health and Nutrition Examination Survey (NHANES; 1988-2010), the geometric mean red blood cell (RBC) folate concentrations (indicative of long-term folate intake) post-fortification (19992000) was $1.5 \times$ the pre-fortification (1988-1994) values [43•]. In the recent Canadian Health Measures Survey, $>40 \%$ of the Canadian population had high postfortification RBC folate concentrations, above the $97 \%$ percentile from the NHANES 1999-2004 data [42].

High folic acid intakes from supplementation and fortification have also resulted in higher levels and prevalence of plasma UMFA compared with the pre-fortification era [41]. For example, plasma UMFA was found in $78 \%$ of a cohort of US postmenopausal women post-fortification [56]. In the Framingham Offspring Cohort, the prevalence of detectable plasma UMFA was 75-81 \% post-fortification compared with 55$72 \%$ pre-fortification in supplement nonusers and users, respectively [57]. Furthermore, the prevalence of high plasma UMFA ( $\geq 85$ th percentile) increased from $9-16$ to $19-24 \%$ in supplement nonusers and users, respectively, after fortification [57]. The post-fortification median plasma UMFA concentrations also doubled in both supplement nonusers and users compared with the pre-fortification values [57]. Most recently, the prevalence of detectable plasma UMFA was $38 \%$ of the US population aged $\geq 60$ years in the NHANES 2001-2002 data set [41].

\section{Potential Adverse Effects of Folic Acid Supplementation}

High intakes and blood levels of folate and folic acid have been linked to several adverse health outcomes, although unequivocal evidence to support these purported associations is lacking $[20,29]$. These include masking of vitamin $B_{12}$ deficiency primarily in elderly [58]; decreased natural killer cell cytotoxicity [56]; resistance to antifolate drugs used against arthritis [59-61], malaria [62], and cancer [63, 64]; an increased risk of insulin resistance and obesity and asthma in children born to folic acid-supplemented mothers [65]; accelerated progression of diabetic nephropathy [66]; an increased risk of cognitive impairment in elderly with suboptimal vita$\min B_{12}$ status $[67,68]$; aberrant patterns and dysregulation of DNA methylation [69]; and the promotion of progression of existing precancerous lesions or cancer $[1,2,15,16]$.

\section{Folate and Colorectal Cancer Risk: Epidemiologic Evidence}

A large body of epidemiologic evidence exists to support, albeit not uniformly consistent, the inverse association between folate status and colorectal cancer risk [70-73]. The portfolio of observational epidemiologic studies suggest a $\sim 20-40 \%$ reduction in the risk of colorectal cancer or its precursor, adenomas, in individuals with high dietary intake and/or blood levels of folate compared with those with low intake and/or levels [70-74]. Molecular epidemiologic studies have shown that genetic variants in the folate metabolic pathway can influence colorectal cancer risk with some studies demonstrating gene-gene and gene-nutrients interactions in further modifying this risk [75-77]. There are some suggestions that folate and folic acid might have differential effects on colorectal cancer risk with some epidemiologic studies showing dietary folate, but not folic acid, to be protective against colorectal cancer [74].

\section{Folate and Colorectal Cancer Risk: Clinical Trials with Colorectal Adenoma Recurrence as the Primary Endpoint}

Folic acid supplementation $(0.4-10 \mathrm{mg} /$ day for 3 months to 2 years) has been shown to improve biomarkers of colorectal 
cancer in small clinical trials [2]. However, these studies are limited by the small sample size, short duration of supplementation, and uncertain validity of the selected biomarkers [2].

Several double-blind, placebo-controlled randomized clinical trials have investigated the effect of folic acid supplementation on the recurrence of colorectal adenomas as the primary endpoint (Table 1). The Greek trial $(n=60)$ [78] and the United Kingdom Colorectal Adenoma Prevention (ukCAP) trial $(n=853)$ [79] reported a null effect of folic acid supplementation $(0.5-1 \mathrm{mg} /$ day for 2-3 years) on adenoma recurrence. However, the Detroit VA trial showed that folic acid supplementation at $5 \mathrm{mg} /$ day for 3 years in subjects with resected adenomas $(n=94)$ significantly reduced the number of recurrent adenomas by $56 \%(p=0.025)$ [80]. Another

Table 1 Summary of placebo-controlled, randomized folic acid chemoprevention trials using colon adenoma recurrence as the primary endpoint

\begin{tabular}{|c|c|c|c|c|}
\hline $\begin{array}{l}\text { Trial name (Year) } \\
\text { (Reference \#) }\end{array}$ & $\begin{array}{l}\text { Number } \\
\text { of subjects }\end{array}$ & $\begin{array}{l}\text { Dose of folic } \\
\text { acid }\end{array}$ & $\begin{array}{l}\text { Duration of } \\
\text { supplementation }\end{array}$ & Outcome \\
\hline Greece (1994) [78] & 60 & $1 \mathrm{mg} /$ day & 2 years & $\begin{array}{l}46 \% \text { reduction in recurrent adenomas } \\
(p=\mathrm{NS})\end{array}$ \\
\hline $\begin{array}{l}\text { Aspirin/Folate Polyp Prevention } \\
\text { Study (AFPPS) (2007) [82] }\end{array}$ & 1021 & $1 \mathrm{mg} /$ day & Up to 6 years & $\begin{array}{l}\text { At } 3 \text {-year colonoscopy: } \\
\text { no effect on recurrence of any adenoma } \\
(\mathrm{RR}=1.04 ; 95 \% \mathrm{CI}, 0.90-1.20) \\
\text { No effect on recurrence of advanced } \\
\text { lesion }^{\mathrm{a}}(\mathrm{RR}=1.32 ; 95 \% \mathrm{CI}, \\
0.90-1.92) \\
\text { No effect on multiplicity }(\mathrm{RR}=1.20 ; 95 \\
\% \mathrm{CI}, 0.80-1.81) \\
\text { At } 6 \text {-year colonoscopy: } \\
\text { no effect on recurrence of any adenoma } \\
(\mathrm{RR}=1.13 ; 95 \% \mathrm{CI}, 0.93-1.37) \\
67 \% \text { increase in recurrence of } \\
\text { advanced lesion }(\mathrm{RR}=1.67 ; 95 \% \\
\text { CI, } 1.00-2.80) \\
\text { Increased multiplicity of recurrent } \\
\text { adenomas }(\mathrm{RR}=2.32 ; 95 \% \mathrm{CI}, \\
1.23-4.35)\end{array}$ \\
\hline Detroit VA Medical Center (2008) [80] & 94 & $5 \mathrm{mg} /$ day & 3 years & $\begin{array}{l}46 \% \text { decrease in multiplicity of } \\
\text { recurrent adenomas ( } 0.86 \text { vs. } 0.36 \text {; } \\
p=0.025)\end{array}$ \\
\hline $\begin{array}{l}\text { United Kingdom Colorectal Adenoma } \\
\text { Prevention Trial (ukCAP) (2008) [79] }\end{array}$ & 853 & $0.5 \mathrm{mg} / \mathrm{day}$ & 3 years & $\begin{array}{l}\text { No effect }(\mathrm{RR}=1.07 ; 95 \% \mathrm{CI} \text {, } \\
0.85-1.34)\end{array}$ \\
\hline $\begin{array}{l}\text { Nurses Health Study/Health } \\
\text { Professionals Follow-Up Study } \\
\text { (NHS-HPFS) (2009) [81] }\end{array}$ & 672 & $1 \mathrm{mg} /$ day & 3 years & $\begin{array}{l}\text { No effect overall }(\mathrm{RR}=0.83 ; 95 \% \mathrm{CI} \text {, } \\
0.59-1.13) \\
\text { Protective in those with baseline plasma } \\
\text { folate } \leq 7.5 \mathrm{ng} / \mathrm{mL}(\mathrm{RR}=0.61 ; 95 \% \\
\mathrm{CI}, 0.42-0.90) \\
\text { No effect in those with baseline plasma } \\
\text { folate }>7.5 \mathrm{ng} / \mathrm{mL}(\mathrm{RR}=1.28 ; 95 \% \\
\text { CI, } 0.82-1.99) \\
\text { No effect in those with baseline plasma } \\
\text { folate }>7.5 \mathrm{ng} / \mathrm{mL}(\mathrm{RR}=1.28 ; 95 \% \\
\text { CI, } 0.82-1.99)\end{array}$ \\
\hline $\begin{array}{l}\text { Combined Analysis of AFPPS, } \\
\text { NHS-HPFS, \& ukCAP (2011) [84] }\end{array}$ & 2632 & $0.5-1 \mathrm{mg} /$ day & $\begin{array}{l}\text { Analysis limited to } 1957 \\
\text { individuals who had at } \\
\text { least } 1 \text { colonoscopic } \\
\text { follow-up at a mean of } \\
30.6 \pm 8.1 \text { months } \\
\text { (range, 6-42 months) }\end{array}$ & $\begin{array}{l}\text { No effect on recurrence of any adenoma } \\
(\mathrm{RR}=0.98 ; 95 \% \mathrm{CI}, 0.82-1.17) \\
\text { No effect on recurrence of advanced } \\
\text { adenoma }(\mathrm{RR}=1.06 ; 95 \% \mathrm{CI}, \\
0.81-1.39)\end{array}$ \\
\hline $\begin{array}{l}\text { Meta-Analysis of AFPPS, NHS-HPFS, } \\
\quad \& \text { ukCAP }(2013)[85 \cdot]\end{array}$ & 2632 & $0.5-1 \mathrm{mg} /$ day & $3-6$ years & $\begin{array}{l}\text { Borderline increase in the rate of } \\
\text { recurrent adenomas }(\mathrm{RR}=1.33 \text {; } \\
95 \% 0.8-1.80 ; p=0.07)\end{array}$ \\
\hline
\end{tabular}

${ }^{a}$ Advanced lesions/adenomas defined as those with $\geq 25 \%$ villous features, high-grade dysplasia, size of $\geq 1 \mathrm{~cm}$, or invasive adenocarcinoma 
trial $(n=672)$ nested in the Nurses' Health Study and the Health Professionals Follow-Up Study (NHS-HPFS) demonstrated that overall, folic acid supplementation at $1 \mathrm{mg}$ /day for 3 years had no effect on adenoma recurrence (RR, 0.83; $95 \%$ CI, 0.59, 1.13) [81]. However, folic acid supplementation significantly reduced the risk of adenoma recurrence by $40 \%$ in those with low baseline plasma folate concentration (defined as $\leq 7.5 \mathrm{ng} / \mathrm{mL}$; RR, $0.61 ; 95 \% \mathrm{CI}, 0.42,0.90$ ), but not in those with high baseline plasma folate concentrations (RR, 1.28; $95 \% \mathrm{CI}, 0.82,1.99)$, compared with the placebo [81].

In contrast, in the Asprin/Folate Polyp Prevention Study (AFPPS), folic acid supplementation at $1 \mathrm{mg}$ /day for 6 years $(n=1021)$ significantly increased the risk of recurrence of advanced adenomas with a high malignant potential by $67 \%(\mathrm{RR}, 1.67 ; 95 \% \mathrm{CI}, 1.00,2.80)$ and the risk of multiple adenomas by 2.3 -fold (RR, 2.32; $95 \%$ CI, 1.23, 4.35) [82]. Furthermore, a 10-year follow-up study of the AFPPS trial showed that those who received folic acid supplementation had a significantly increased risk of prostate cancer [83]. A plausible mechanistic explanation proposed for these observations is that folic acid supplementation might have promoted the progression of undiagnosed preexisting (pre)neoplastic lesions in the colorectum and prostate in these highly predisposed individuals $[2,16]$.

A combined analysis (Table 1 ) of the three largest clinical trials (AFPPS, NHS-HPFS, and ukCAP; $n=2632 ; 0.5-$ $1.0 \mathrm{mg} /$ day folic acid) found no effect of folic acid supplementation on the risk of recurrence of all adenomas (RR, 0.98; $95 \% \mathrm{CI}, 0.83,1.17$ ) or of advanced adenomas (RR, 1.06; $95 \%$ CI, 0.81, 1.39) [84]. In fact, this combined analysis demonstrated a decreased risk, albeit nonsignificant, of adenoma recurrence among individuals with low baseline plasma folate (defined as $<11 \mathrm{nmol} / \mathrm{L}$ ) [84]. However, a more recent meta-analysis of the same three clinical trials (Table 1) reported a borderline $33 \%$ increase in the risk of recurrent adenomas (RR, 1.33; $95 \% \mathrm{CI}, 0.98,1.80 ; p=0.07$ ) [85•].

\section{Folate and Colorectal Cancer Risk: Clinical Trials with Cancer or Colorectal Cancer Incidence or Mortality as a Secondary Endpoint}

Combined or meta-analyses of several large randomized clinical trials that investigated the effect of folic acid supplementation with or without other B vitamins on cardiovascular disease outcomes as the primary endpoint also determined cancer incidence and/or mortality as the secondary endpoint. These analyses reported either a tumor-promoting [86] or null [31] effect. Another meta-analysis of the AFPPS, NHS-HPFS, and ukCAP trials and 3 other clinical trials of $\mathrm{B}$ vitamins that examined the risk of colorectal cancer as the secondary endpoint found no significant effect of folic acid supplementation on colorectal cancer risk [87].

A meta-analysis of 10 clinical trials $(n=38,233)$ including the AFPPS, NHS-HPFS, and ukCAP trials and 7 trials that examined the effect of B vitamins on cardiovascular outcomes as the primary endpoint and cancer incidence/mortality as the secondary endpoint again reported a marginally statistically significant $7 \%$ increase in overall cancer incidence (RR, $1.07 ; 95 \% \mathrm{CI}, 1.00,1.14$ ) [88•]. A meta-analysis of 6 clinical trials reporting prostate cancer incidence showed a $24 \%$ increase in prostate cancer incidence (RR, 1.24; $95 \% \mathrm{CI}, 1.03$, 1.49) [88 ]. No significant effect of folic acid supplementation on the incidence of other cancer types was noted in this metaanalysis [88 ]. A more recent meta-analysis of 13 clinical trials (10 trials for prevention of cardiovascular disease $[n=46,969]$ and the AFPPS, NHS-HPFS, and ukCAP trials $[n=2652]$ ) found a marginally statistically significant $6 \%$ increase in overall cancer incidence (RR, 1.06; $95 \% \mathrm{CI}, 0.99,1.13$ ) [85•]. For colorectal and prostate cancers, the risk estimate was $1.07(95 \% \mathrm{CI}, 0.83,1.37)$ and $1.15(95 \% \mathrm{CI}, 0.94$, $1.41)$, respectively [85•].

\section{Folate and Colorectal Cancer Risk: Dual Modulatory Effects of Folate on Colorectal Carcinogenesis Observed in Animal Studies}

The potential tumor-promoting effect of folic acid supplementation observed in some of the abovementioned clinical trials is supported by the prior observations made in animal studies, which have suggested dual modulatory effects of folate on cancer development and progression depending on the stage of cell transformation at the time of folate intervention (Fig. 1) $[2,15,16]$. Folate deficiency has an inhibitory, whereas folic acid supplementation has a promoting, effect on the progression of established (pre)neoplastic lesions in the colorectum [89], small intestine [90, 91], and mammary glands [92]. In contrast, folate deficiency predisposes normal tissues to neoplastic initiation, and modest levels of folic acid supplementation suppress, whereas supraphysiologic supplemental doses enhance, neoplastic transformation in the colorectum [93, 94] and small intestine [90, 91].

\section{Biological Mechanisms of the Dual Modulatory Effects of Folate on Cancer Development and Progression}

The dual effects of folate on cancer development and progression are most likely related to folate's essential role in nucleotide biosynthesis (Table 2) [2, 7]. A large body of in vivo and in vitro studies indicates that folate deficiency can initiate neoplastic transformation in normal colorectal epithelial cells 


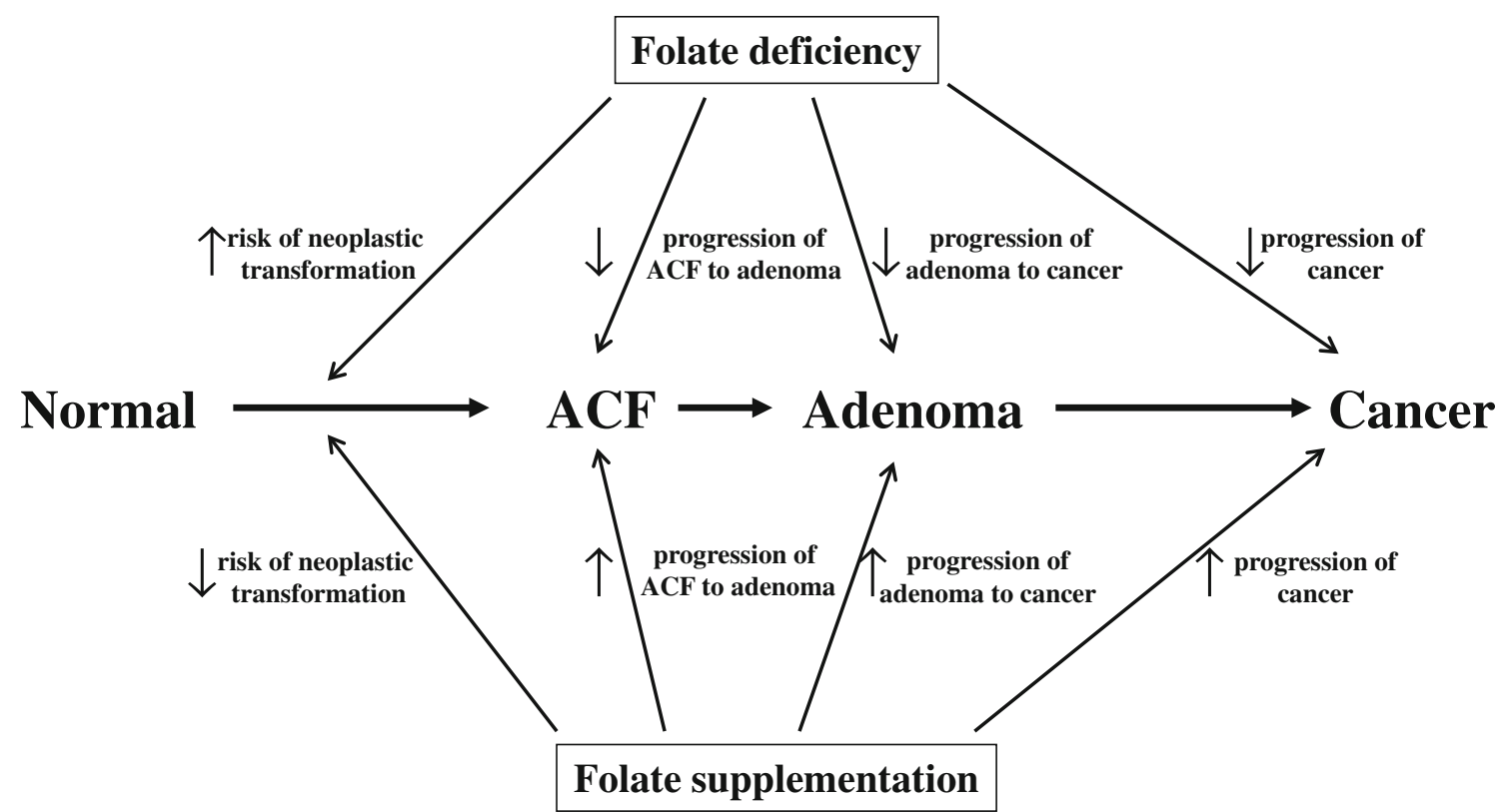

Fig. 1 Dual modulatory role of folate in colorectal carcinogenesis depending on the stage of cell transformation at the time of folate intervention. In normal tissues, folate deficiency predisposes them to neoplastic transformation, while modest levels of folic acid supplementation suppress, whereas supraphysiologic supplemental doses enhance, the development and progression of (pre)neoplastic lesions in the colorectum. In established (pre)neoplastic lesions, however, folate deficiency has an inhibitory effect, whereas folic acid supplementation has a promoting effect on the progression of theses lesions (adapted with permission from Kim [2])

of these (pre)neoplastic lesions, similar to the cytotoxic mechanism of antifolate-based chemotherapy $[2,16]$. On the other hand, folic acid supplementation may promote the progression of established (pre)neoplastic lesions in the colorectum by providing nucleotide precursors to rapidly replicating cells for accelerated proliferation and progression $[2,16]$.

Aberrant patterns and dysregulation of DNA methylation is another candidate mechanism for the dual effects of folate on colorectal cancer risk [7, 69, 101, 102] (Table 2). In normal colorectal epithelial cells, folate deficiency may cause global DNA hypomethylation with consequent genomic instability, leading to neoplastic transformation $[2,7]$. In transformed
Table 2 Potential mechanisms for the dual modulatory effect of folate on colorectal cancer development and progression
Normal colonic epithelial cells

Folate deficiency increases colorectal cancer risk

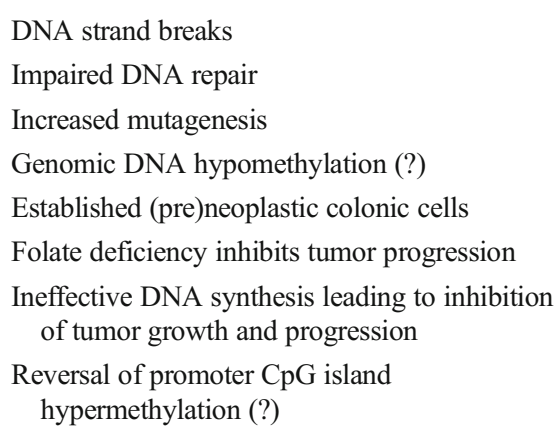

DNA strand breaks

Impaired DNA repair

Increased mutagenesis

Genomic DNA hypomethylation (?)

Established (pre)neoplastic colonic cells

Folate deficiency inhibits tumor progression

Ineffective DNA synthesis leading to inhibition of tumor growth and progression

Reversal of promoter $\mathrm{CpG}$ island hypermethylation (?)

Folic acid supplementation decreases colorectal cancer risk

Increased DNA stability and integrity

Optimal DNA repair

Protection against mutagenesis

Prevention of aberrant DNA methylation (?)

Folic acid supplementation promotes tumor progression

Provision of nucleotide precursors for proliferation and growth of neoplastic cells

De novo methylation of promoter $\mathrm{CpG}$ islands of tumor suppressor genes leading to gene inactivation (?)

Hypermutability of methylated cytosine in $\mathrm{CpG}$ (?) 
colorectal epithelial cells, however, folate deficiency may suppress tumor progression by reversing promoter cytosine-guanine $(\mathrm{CpG})$ island DNA methylation of tumor suppressor and other cancer-related genes; this leads to reactivation of these epigenetically silenced genes [2, 7]. In normal colorectal epithelial cells, folic acid supplementation may prevent global DNA hypomethylation, thereby reducing the risk of neoplastic transformation by ensuring genomic stability [2, 7]. In transformed colorectal epithelial cells, however, folic acid supplementation may promote tumor progression by inducing de novo methylation of the promoter $\mathrm{CpG}$ island of tumor suppressor and cancer-related genes, thereby silencing these genes [2, 7]. However, the effects of folate deficiency and folic acid supplementation on DNA methylation are highly complex as they are gene- and site-specific and depend on species, cell type, target organ, and stage of transformation as well as on the timing, degree, and duration of folate intervention $[2,7$, 69, 101-103].

\section{Folic Acid Fortification and Colorectal Cancer Risk}

The potential tumor-promoting effect of folic acid supplementation on (pre)neoplastic cells observed in animal and some clinical studies has raised concerns over whether or not the drastically increased intake and blood levels of folate and folic acid resulting from folic acid fortification and prevalent supplemental folic acid use would increase cancer incidence and mortality in North America [7, 19, 104]. For colorectal cancer, a large segment of the North American population, in particular, those $\geq 50$ years of age, is at risk of being exposed to the potential tumor-promoting effect of folic acid $[2,7,16,101$, 104]. Approximately, 25-50\% of people by age 50 years in North America have been estimated to harbor asymptomatic colorectal adenomas [105]. Even a greater number of North Americans likely harbor indolent precancerous lesions such as aberrant crypt foci, the probable earliest precursor of colorectal cancer [106], or microscopic adenomas in the colon, and folic acid may accelerate the progression of these early precursor lesions to colorectal adenomas and cancer $[2,7,16$, 101, 104]. A recent study using the NHANES 2003-2006 data has reported that total folate and folic acid intakes are highest for those aged $\geq 50$ years, and $\sim 5 \%$ of US adults aged 51-70 years exceed the tolerable upper intake level $(>1000 \mu \mathrm{g})$ of folic acid each day [48], likely from a regular consumption of folic acid supplements [107].

Two ecologic studies addressed this important public health concern by examining a temporal post-fortification trend of colorectal cancer incidence in the USA, Canada, and Chile [108, 109]. These studies found a transient increase in colorectal cancer incidence in these countries following fortification and put forward a provocative hypothesis that folic acid fortification may have been wholly or partly responsible for this observation [108, 109]. However, these ecological studies are limited by several confounders and hence cannot provide definite evidence to support an etiologic role of folic acid fortification in the observed transient increase in colorectal cancer incidence in North America and Chile post-fortification [16]. One interpretation of this observation is that folic acid fortification increased the proliferation and growth of existing, undiagnosed precancerous lesions, rendering them clinically evident, which resulted in a transient increase in incidence [5]. After this tumor-promoting effect of folic acid fortification on existing precancerous lesions was completed, folic acid fortification has exerted a protective effect against the development of de novo colorectal adenomas and cancers, resulting in a steady decline of colorectal cancer incidence [5].

Reassuringly, two large population-based prospective studies have reported a decreasing trend of colorectal cancer incidence post-fortification in the USA $[110,111]$. More importantly, these studies did not demonstrate a colorectal cancerpromoting effect of the drastically increased folate/folic acid intake post-fortification $[110,111]$. These studies are, however, associated with several limitations including the small number of individuals who would be most susceptible to the cancer-promoting effect of high folate intake [110] and the insufficient number of individuals consuming very high amounts of folate [111]. Nevertheless, these studies provide some reassurance that high folate/folic acid intake postfortification is not associated with cancer promotion in the general population [107]. However, this possibility still remains a significant concern in specific susceptible subgroups [107].

A Canadian study [112] provides further reassurance regarding the safety of folic acid fortification on pediatric cancer risk. In this study, the post-fortification incidence of neuroblastoma among children $\leq 17$ years of age was significantly decreased by $60 \%$ compared with pre-fortification [112]. In contrast, the post-fortification incidence of infant acute lymphoblastic leukemia and hepatoblastoma did not differ significantly from the pre-fortification incidence [112].

\section{Maternal and Early Life Folate Nutrition and Colorectal Cancer Risk in the Offspring}

Intrauterine exposure of the developing fetus to folate and folic acid has significantly increased in North America owing to mandatory folic acid fortification, widespread supplemental use of folic acid, and periconceptional folic acid supplementation $[7,113 \bullet]$. Women of reproductive age are recommended to consume $0.4 \mathrm{mg}$ of folic acid per day from fortified foods or supplements, or both, 2-3 months prior to conception and during pregnancy [21]. Studies from Canada and the USA report the majority of women now consume supplements 
containing folic acid prior to and during pregnancy $[114,115]$. Considering the important role of folate in nucleotide biosynthesis and DNA methylation [8] and hence cancer development and progression, the potential effect of high maternal and early life folate and folic acid exposure on cancer risk in the offspring has recently garnered significant attention.

Aberrant patterns or dysregulation of DNA methylation in utero and in the early postnatal period has been considered as one of the underlying mechanisms by which maternal and early postnatal folate nutrition may modulate cancer risk in the offspring $[7,69,113 \cdot]$. DNA methylation patterns are reprogrammed during the embryogenic stage and maintained during the postnatal period $[7,69,113 \cdot]$. As a result, DNA methylation during this critical period of development is highly susceptible to the in utero and early postnatal nutritional, hormonal, and metabolic milieu [7, 69, 113•]. In particular, one-carbon nutrients including folate can have a significant effect on DNA methylation programming during the in utero and postnatal periods in the offspring, which may influence disease susceptibility, including cancer risk, in adulthood [7, $69,113 \cdot$ ]. Proof-of-principle studies using the agouti viable yellow $\left(\mathrm{A}^{\mathrm{vy}} / \mathrm{a}\right)$ [116-118] and Axin Fused (Axin $\left.{ }^{\mathrm{FU}}\right)$ [119] mouse models have provided convincing evidence that maternal methyl donor supplementation, including folic acid, can significantly change promoter $\mathrm{CpG}$ island DNA methylation of the $A^{v y} / a$ and $A x{ }^{F U}$ genes and associated phenotypes (coat color and straightness of the tail, respectively) and disease susceptibility (obesity, hypertension, insulin resistance, and cancer) in the offspring. Animal studies have also shown that maternal supplementation of folic acid alone can modulate global and gene-specific DNA methylation in the offspring [113•, 120-124]. The modulatory effect of periconceptional folic acid supplementation on global DNA methylation in the offspring has also been shown, albeit equivocally, in small human studies [125-127].

Two recent animal studies (the azoxymethane rat model and $A p c^{1638 N}$ mouse model, respectively) have demonstrated the protective effect of maternal folic acid supplementation alone [124] or in combination with vitamins $\mathrm{B}_{2}, \mathrm{~B}_{6}$, and $\mathrm{B}_{12}$ [128] on colorectal cancer and small intestinal tumors, respectively, in the offspring. In contrast, another recent study using a chemical carcinogen rat model has shown that maternal and postweaning folic acid supplementation significantly increased the incidence of mammary tumors in the offspring [123].

To date, no human studies have investigated the effect of maternal folic acid supplementation on colorectal cancer risk in the offspring. However, the effects of periconceptional folate intake or folic acid supplementation on other cancers have been examined in epidemiologic studies with inconsistent results [129]. While a protective effect of periconceptional maternal folic acid supplementation on several pediatric cancers has been shown in some studies [130-134], other studies have not confirmed this protective effect [135-137] and some have even shown an increased risk [132]. A meta-analysis of seven of these studies reported a protective effect of folic acidcontaining multivitamin supplements on childhood leukemia including acute lymphocytic leukemia and on pediatric brain tumors, especially neuroblastoma [138]. The major limitation of these epidemiologic studies is the uncertainty concerning whether the effect on cancer risk was specific to folic acid or was attributable to other vitamins in the supplements [138].

\section{Gaps in Knowledge and Research Questions}

Several important issues regarding the effect of folic acid supplementation on colorectal cancer prevention remain to be clarified. Firstly, the safe and effective dose range of folic acid supplementation on colorectal cancer prevention has not been established in humans and animals $[2,7,16,101]$. In this regard, the threshold level above which folic acid supplementation may exert the tumor-promoting effect on (pre)neoplastic lesions as well as dose-response of such an effect are unknown and have not been established in humans or in animals [2, 7, $16,101]$. Extrapolating data from animal studies is problematic because of inherent differences in folate absorption and metabolism and cancer development between humans and rodents $[2,7,16,101]$. Secondly, whether the potential tumorpromoting effect of high folate status is specific to synthetic folic acid or is generalizable to naturally occurring folates, such as 5-methyltetrahydrofolate, present in foods is unknown [2, 7, $16,101]$. It has been speculated that most, if not all, of the purported adverse health effects associated with high folate status, including cancer promotion, are attributable to folic acid and not natural folates [20]. However, metabolic and biologic effects of folic acid have not been systematically compared with those of naturally occurring folates [139]. Whether or not 5-methyltetrahydrofolate is a safer and effective alternative to folic acid in providing supplemental levels of folate is an important research question. Thirdly, the critical stage of cell transformation at which folic acid supplementation may exert a tumor-promoting effect has not yet unequivocally been established [2, 7, 16, 101]. Fourthly, the effect of the drastically increased in utero and early life exposure to folic acid resulting from folic acid fortification and periconceptional folic acid supplementation on offspring's cancer risk later on in life has not been extensively investigated [2, 7, 16, 101]. Although folic acid fortification and periconceptional folic acid supplementation have significantly reduced neural tube defect rates by $15-50 \%$ [44-46], whether or not the significantly increased intrauterine and early life exposure to folate and folic acid would influence cancer risk in the offspring is an important public health concern $[2,7,16,101]$. 


\section{Conclusions}

Whether or not folic acid supplementation can prevent the development of colorectal cancer remains a highly controversial, complex, and unresolved issue at present. The portfolio of evidence from animal and human studies collectively suggests that folic acid supplementation of modest, but not excessively high, levels may prevent neoplastic initiation in the colorectum but it may promote the progression of established precancerous lesions. Folic acid supplementation therefore seems to possess dual modulatory effects on colorectal cancer prevention, depending on the stage of cell transformation at the time of intervention and the dose of supplementation. Biologically plausible mechanisms for the dual modulatory effects do exist and render considerable support for the observations made in animal and epidemiologic studies and clinical trials.

Given the lack of compelling supportive evidence and the potential tumor-promoting effect, folic acid supplementation cannot be considered as a chemopreventive agent against colorectal or any other cancer in the general population at present $[2,7,16,101]$. In particular, folic acid supplementation should be avoided in highly predisposed and susceptible individuals at risk of developing colorectal cancer (e.g., those with previous colorectal adenomas and those suspected of harboring indolent precursor lesions of colorectal cancer such as aberrant crypt foci, microscopic adenomas, and adenomas) $[2,7,16,101]$. Furthermore, folic acid supplementation should not be routinely recommended to those $\geq 50$ years of age, an age group with a high intake of folic acid [48] and with a high prevalence of colorectal adenomas or other precursor lesions $[2,7,16,101]$. Corollary to this, in specific circumstances, modest supplemental doses of folic acid may be considered for colorectal cancer prevention before the development of precursor lesions in the colorectum or in individuals free of any evidence of (pre)neoplastic foci $[2,7,16,101]$. However, screening for the presence of (pre)neoplastic foci in the colorectum in the general population is almost an impossible task $[2,7,16,101]$. Given the inverse association between dietary folate intake and colorectal cancer risk as well as a more consistent protective effect associated with natural folates versus synthetic folic acid observed in epidemiologic studies, optimal intake of folate should be obtained from natural dietary sources for a possible colorectal cancer preventive effect.

The pubic health ramifications of the potential cancerpromoting effect of folic acid fortification and supplementation are quite serious. Although recent population-based epidemiologic studies have provided some reassurance that the drastically increased folate and folic acid intake post-fortification has not resulted in an increased incidence of colorectal cancer in the USA and in fact, there has been a decreasing trend of colorectal cancer incidence post-fortification, these studies are associated with significant limitations [110, 111]. As such, safety and adverse effects, with a particular attention to cancer incidence and mortality, of the dramatically increased folate status in North America resulting from fortification and prevalent folic acid supplemental use require continued careful monitoring $[2,7,16,101]$. As eloquently stated by Mason, "the weight of evidence used to disprove a potentially harmful phenomenon should be roughly proportional to the severity and extent of damage that could be incurred by the phenomenon" [107]. At present, the potential tumorpromoting effect on the progression of (pre)neoplastic lesions remains the most controversial and potentially most serious adverse effect of folic acid supplementation and fortification. As such, further studies are warranted to clarify this issue.

Funding This work was supported in part by the Canadian Institutes of Health Research (Grant \#14126).

\section{Compliance with Ethical Standards}

Conflict of Interest Young-In Kim declares no conflict of interest.

Human and Animal Rights and Informed Consent This article does not contain any studies with human or animal subjects performed by any of the authors.

\section{References}

Papers of particular interest, published recently, have been highlighted as:

- Of importance

1. Kim YI. Folate and carcinogenesis: evidence, mechanisms, and implications. J Nutr Biochem. 1999;10:66-88.

2. Kim YI. Folate and colorectal cancer: an evidence-based critical review. Mol Nutr Food Res. 2007;51(3):267-92.

3. Kim YI. Folate: a magic bullet or a double edged sword for colorectal cancer prevention? Gut. 2006;55:1387-9.

4. Mason JB, Kim SJ. Revisiting the goldilocks phenomenon: folate and colorectal cancer risk. Am J Gastroenterol. 2010;105(9):1914-6.

5. Miller JW, Ulrich CM. Folic acid and cancer-where are we today? Lancet. 2013;381(9871):974-6.

6. Ulrich CM, Potter JD. Folate and cancer-timing is everything. JAMA. 2007;297(21):2408-9.

7. Kim SE, Masih S, Kim YI. Folate, DNA methylation and colorectal cancer. In: Ho E, Domann F, editors. Nutrition and epigenetics. Boca Raton: Taylor \& Francis Group CRC Press; 2014. p. 113-61.

8. Shane B. Folate chemistry and metabolism. In: Bailey LB, editor. Folate in health and disease. Boca Raton: CRC Press; 2010. p. 1-24.

9. Bills ND, Hinrichs SH, Morgan R, Clifford AJ. Delayed tumor onset in transgenic mice fed a low-folate diet. J Natl Cancer Inst. 1992;84(5):332-7. 
10. Little PA, Sampath A, Paganelli V. The effect of folic acid and its antagonists on rous chicken sarcoma. Trans NY Acad Sci Series II. 1948;10:91-8.

11. Rosen F, Nichol CA. Inhibition of the growth of an amethopterinrefractory tumor by dietary restriction of folic acid. Cancer Res. 1962;22:495-500.

12. Faber S, Cutler EC, Hawkins JW, Harrison JH, Peirce EC, Lenx GG. The action of pteroylglutamic conjugates on man. Science. 1947;106:619-21.

13. Heinle RW, Welch AD. Experiments with pteroylglutamic acid and pteroylglutamic acid deficiency in human leukemia. J Clin Invest. 1948;27(4):539.

14. Farber S, Diamond LK, Mercer RD, Sylvester RF, Wolff VA. Temporary remission of acute leukemia in children produced by folic acid antagonist, 4-aminopteroyl glutamic acid (aminopterin). N Engl J Med. 1948;238:787-93.

15. Kim YI. Role of folate in colon cancer development and progression. J Nutr. 2003;133:3731S-9S.

16. Kim YI. Folic acid supplementation and cancer risk: point. Cancer Epidemiol Biomarkers Prev. 2008;17(9):2220-5.

17. Campbell NR. How safe are folic acid supplements? Arch Intern Med. 1996;156(15):1638-44.

18. Lucock M. Is folic acid the ultimate functional food component for disease prevention? BMJ. 2004;328(7433):211-4.

19. Kim YI. Folic acid fortification and supplementation — good for some but not so good for others. Nutr Rev. 2007;65(11):504-11.

20. Smith AD, Kim YI, Refsum H. Is folic acid good for everyone? Am J Clin Nutr. 2008;87(3):517-33.

21. Institute of Medicine. Folate. Dietary reference intakes for thiamin, riboflavin, niacin, vitamin B6, folate, vitamin B12, pantothenic acid, biotin, and choline. Washington: National Academy Press; 1998. p. 196-305.

22. Wright AJ, Dainty JR, Finglas PM. Folic acid metabolism in human subjects revisited: potential implications for proposed mandatory folic acid fortification in the UK. Br J Nutr. 2007;98(4): 667-75.

23. Kelly P, McPartlin J, Goggins M, Weir DG, Scott JM. Unmetabolized folic acid in serum: acute studies in subjects consuming fortified food and supplements. Am J Clin Nutr. 1997;65(6):1790-5.

24. Sweeney MR, McPartlin J, Weir DG, Daly S, Pentieva K, Daly L, et al. Evidence of unmetabolised folic acid in cord blood of newborn and serum of 4-day-old infants. Br J Nutr. 2005;94(5): 727-30.

25. Aufreiter S, Gregory 3rd JF, Pfeiffer CM, Fazili Z, Kim YI, Marcon N, et al. Folate is absorbed across the colon of adults: evidence from cecal infusion of (13)C-labeled [6S]-5-formyltetrahydrofolic acid. Am J Clin Nutr. 2009;90(1):116-23.

26. Camilo E, Zimmerman J, Mason JB, Golner B, Russell R, Selhub $\mathrm{J}$, et al. Folate synthesized by bacteria in the human upper small intestine is assimilated by the host. Gastroenterology. 1996;110(4):991-8.

27. Rong N, Selhub J, Goldin BR, Rosenberg IH. Bacterially synthesized folate in rat large intestine is incorporated into host tissue folyl polyglutamates. J Nutr. 1991;121(12):1955-9.

28. Lakoff A, Fazili Z, Aufreiter S, Pfeiffer CM, Connolly B, Gregory 3rd JF, et al. Folate is absorbed across the human colon: evidence by using enteric-coated caplets containing 13C-labeled [6S]-5formyltetrahydrofolate. Am J Clin Nutr. 2014;100(5):1278-86.

29. Warzyszynska JE, Kim YI. Folate in human health and disease. eLife Science. Chichester: Wiley; 2014. doi:10.1002/ 9780470015902.a0002268.pub2.

30. Clarke R, Halsey J, Bennett D, Lewington S. Homocysteine and vascular disease: review of published results of the homocysteinelowering trials. J Inherit Metab Dis. 2011;34(1):83-91.
31. Clarke R, Halsey J, Lewington S, Lonn E, Armitage J, Manson JE, et al. Effects of lowering homocysteine levels with B vitamins on cardiovascular disease, cancer, and cause-specific mortality: metaanalysis of 8 randomized trials involving 37485 individuals. Arch Intern Med. 2010;170(18):1622-31.

32. Lonn E, Yusuf S, Arnold MJ, Sheridan P, Pogue J, Micks M, et al. Homocysteine lowering with folic acid and B vitamins in vascular disease. N Engl J Med. 2006;354(15):1567-77.

33. Wang X, Qin X, Demirtas H, Li J, Mao G, Huo Y, et al. Efficacy of folic acid supplementation in stroke prevention: a meta-analysis. Lancet. 2007;369(9576):1876-82.

34. Durga J, van Boxtel MP, Schouten EG, Kok FJ, Jolles J, Katan $\mathrm{MB}$, et al. Effect of 3-year folic acid supplementation on cognitive function in older adults in the FACIT trial: a randomised, double blind, controlled trial. Lancet. 2007;369(9557):208-16.

35. Douaud G, Refsum H, de Jager CA, Jacoby R, Nichols TE, Smith SM, et al. Preventing Alzheimer's disease-related gray matter atrophy by B-vitamin treatment. Proc Natl Acad Sci U S A. 2013;110(23):9523-8.

36. Smith AD, Smith SM, de Jager CA, Whitbread P, Johnston C, Agacinski G, et al. Homocysteine-lowering by B vitamins slows the rate of accelerated brain atrophy in mild cognitive impairment: a randomized controlled trial. PLoS One. 2010;5(9), e12244.

37. Balk EM, Raman G, Tatsioni A, Chung M, Lau J, Rosenberg IH. Vitamin B6, B12, and folic acid supplementation and cognitive function: a systematic review of randomized trials. Arch Intern Med. 2007;167(1):21-30.

38. McMahon JA, Green TJ, Skeaff CM, Knight RG, Mann JI, Williams SM. A controlled trial of homocysteine lowering and cognitive performance. N Engl J Med. 2006;354(26):2764-72.

39. Food and Drug Administration. Food standards: amendment of standards of identity for enriched grain products to require addition of folic acid. Final rule. 21 CFR Parts 136, 137, and 139. Fed Regist. 1996;61(44):8781-807.

40. Health Canada. Regulations amending the Food and Drug Regulations (1066). Canada Gazette, Part 1. 1997;131:3702-37.

41. Bailey RL, Mills JL, Yetley EA, Gahche JJ, Pfeiffer CM, Dwyer JT, et al. Unmetabolized serum folic acid and its relation to folic acid intake from diet and supplements in a nationally representative sample of adults aged $>$ or $=60 \mathrm{y}$ in the United States. Am J Clin Nutr. 2010;92(2):383-9.

42. Colapinto CK, O'Connor DL, Tremblay MS. Folate status of the population in the Canadian Health Measures Survey. CMAJ. 2011;183(2):E100-6.

43. Pfeiffer CM, Hughes JP, Lacher DA, Bailey RL, Berry RJ, Zhang $\mathrm{M}$, et al. Estimation of trends in serum and RBC folate in the U.S. population from pre- to postfortification using assay-adjusted data from the NHANES 1988-2010. J Nutr. 2012;142(5):886-93. This epidemiologic survey reports a significant increase in serum and $\mathrm{RBC}$ folate concentration in the US population following mandatory folic acid fortification in 1998.

44. De Wals P, Tairou F, Van Allen MI, Uh SH, Lowry RB, Sibbald B, et al. Reduction in neural-tube defects after folic acid fortification in Canada. N Engl J Med. 2007;357(2):135-42.

45. Williams J, Mai CT, Mulinare J, Isenburg J, Flood TJ, Ethen M, et al. Updated estimates of neural tube defects prevented by mandatory folic acid fortification-United States, 1995-2011. MMWR Morb Mortal Wkly Rep. 2015;64(1):1-5.

46. Center for Disease Control and Prevention. CDC Grand Rounds: additional opportunities to prevent neural tube defects with folic acid fortification. MMWR Morb Mortal Wkly Rep. 2010;59(31): 980-4.

47. Radimer K, Bindewald B, Hughes J, Ervin B, Swanson C, Picciano MF. Dietary supplement use by US adults: data from the National Health and Nutrition Examination Survey, 19992000. Am J Epidemiol. 2004;160(4):339-49. 
48. Bailey RL, Dodd KW, Gahche JJ, Dwyer JT, McDowell MA, Yetley EA, et al. Total folate and folic acid intake from foods and dietary supplements in the United States: 2003-2006. Am J Clin Nutr. 2010;91(1):231-7.

49. Wilson RD, Johnson JA, Wyatt P, Allen V, Gagnon A, Langlois S, et al. Pre-conceptional vitamin/folic acid supplementation 2007: the use of folic acid in combination with a multivitamin supplement for the prevention of neural tube defects and other congenital anomalies. J Obstet Gynaecol Can. 2007;29(12):1003-26.

50. Giovannucci E, Chan AT. Role of vitamin and mineral supplementation and aspirin use in cancer survivors. J Clin Oncol. 2010;28(26):4081-5.

51. Velicer CM, Ulrich CM. Vitamin and mineral supplement use among US adults after cancer diagnosis: a systematic review. J Clin Oncol. 2008;26(4):665-73.

52. Sandler RS, Halabi S, Kaplan EB, Baron JA, Paskett E, Petrelli NJ. Use of vitamins, minerals, and nutritional supplements by participants in a chemoprevention trial. Cancer. 2001;91(5): 1040-5.

53. Greenlee H, White E, Patterson RE, Kristal AR. Supplement use among cancer survivors in the Vitamins and Lifestyle (VITAL) study cohort. J Altern Complement Med. 2004;10(4):660-6.

54. Satia JA, Campbell MK, Galanko JA, James A, Carr C, Sandler RS. Longitudinal changes in lifestyle behaviors and health status in colon cancer survivors. Cancer Epidemiol Biomarkers Prev. 2004;13(6):1022-31.

55. Holmes RS, Zheng Y, Baron JA, Li L, McKeown-Eyssen G, Newcomb PA, et al. Use of folic acid-containing supplements after a diagnosis of colorectal cancer in the Colon Cancer Family Registry. Cancer Epidemiol Biomarkers Prev. 2010;19(8):2023-34.

56. Troen AM, Mitchell B, Sorensen B, Wener MH, Johnston A, Wood B, et al. Unmetabolized folic acid in plasma is associated with reduced natural killer cell cytotoxicity among postmenopausal women. J Nutr. 2006;136(1):189-94.

57. Kalmbach RD, Choumenkovitch SF, Troen AM, D'Agostino R, Jacques PF, Selhub J. Circulating folic acid in plasma: relation to folic acid fortification. Am J Clin Nutr. 2008;88(3):763-8.

58. Reynolds E. Vitamin B12, folic acid, and the nervous system. Lancet Neurol. 2006;5(11):949-60.

59. Dervieux T, Furst D, Lein DO, Capps R, Smith K, Caldwell J, et al. Pharmacogenetic and metabolite measurements are associated with clinical status in patients with rheumatoid arthritis treated with methotrexate: results of a multicentred cross sectional observational study. Ann Rheum Dis. 2005;64(8):1180-5.

60. Khanna D, Park GS, Paulus HE, Simpson KM, Elashoff D, Cohen $\mathrm{SB}$, et al. Reduction of the efficacy of methotrexate by the use of folic acid: post hoc analysis from two randomized controlled studies. Arthritis Rheum. 2005;52(10):3030-8.

61. Salim A, Tan E, Ilchyshyn A, Berth-Jones J. Folic acid supplementation during treatment of psoriasis with methotrexate: a randomized, double-blind, placebo-controlled trial. Br J Dermatol. 2006;154(6):1169-74.

62. Carter JY, Loolpapit MP, Lema OE, Tome JL, Nagelkerke NJ, Watkins WM. Reduction of the efficacy of antifolate antimalarial therapy by folic acid supplementation. Am J Trop Med Hyg. 2005;73(1):166-70.

63. Hooijberg JH, de Vries NA, Kaspers GJ, Pieters R, Jansen G, Peters GJ. Multidrug resistance proteins and folate supplementation: therapeutic implications for antifolates and other classes of drugs in cancer treatment. Cancer Chemother Pharmacol. 2006;58(1):1-12.

64. Hooijberg JH, Jansen G, Assaraf YG, Kathmann I, Pieters R, Laan $\mathrm{AC}$, et al. Folate concentration dependent transport activity of the multidrug resistance protein 1 (ABCC1). Biochem Pharmacol. 2004;67(8):1541-8.
65. Yajnik CS, Deshpande SS, Jackson AA, Refsum H, Rao S, Fisher DJ, et al. Vitamin B12 and folate concentrations during pregnancy and insulin resistance in the offspring: the Pune Maternal Nutrition Study. Diabetologia. 2008;51(1):29-38.

66. House AA, Eliasziw M, Cattran DC, Churchill DN, Oliver MJ, Fine A, et al. Effect of B-vitamin therapy on progression of diabetic nephropathy: a randomized controlled trial. JAMA. 2010;303(16):1603-9.

67. Morris MC, Evans DA, Bienias JL, Tangney CC, Hebert LE, Scherr PA, et al. Dietary folate and vitamin B12 intake and cognitive decline among community-dwelling older persons. Arch Neurol. 2005;62(4):641-5.

68. Morris MS, Jacques PF, Rosenberg IH, Selhub J. Folate and vitamin B-12 status in relation to anemia, macrocytosis, and cognitive impairment in older Americans in the age of folic acid fortification. Am J Clin Nutr. 2007;85(1):193-200.

69. Ly A, Hoyt L, Crowell J, Kim YI. Folate and DNA methylation. Antioxid Redox Signal. 2012;17(2):302-26.

70. Giovannucci E. Epidemiologic studies of folate and colorectal neoplasia: a review. J Nutr. 2002;132(8 Suppl):2350S-5S.

71. Kim DH, Smith-Warner SA, Spiegelman D, Yaun SS, Colditz GA, Freudenheim JL, et al. Pooled analyses of 13 prospective cohort studies on folate intake and colon cancer. Cancer Causes Control. 2010;21(11):1919-30.

72. Sanjoaquin MA, Allen N, Couto E, Roddam AW, Key TJ. Folate intake and colorectal cancer risk: a meta-analytical approach. Int J Cancer. 2005;113(5):825-8.

73. Chen J, Xu X, Liu A, Ulrich CM. Folate and cancer: epidemiological perspective. In: Bailey LB, editor. Folate in health and disease. 2nd ed. Boca Raton: CRC Press; 2010. p. 205-34.

74. Kennedy DA, Stern SJ, Moretti M, Matok I, Sarkar M, Nickel C, et al. Folate intake and the risk of colorectal cancer: a systematic review and meta-analysis. Cancer Epidemiol. 2011;35(1):2-10.

75. de Jong MM, Nolte IM, te Meerman GJ, van der Graaf WT, de Vries EG, Sijmons RH, et al. Low-penetrance genes and their involvement in colorectal cancer susceptibility. Cancer Epidemiol Biomarkers Prev. 2002;11(11):1332-52.

76. Houlston RS, Tomlinson IP. Polymorphisms and colorectal tumor risk. Gastroenterology. 2001;121(2):282-301.

77. Sharp L, Little J. Polymorphisms in genes involved in folate metabolism and colorectal neoplasia: a HuGE review. Am J Epidemiol. 2004;159(5):423-43.

78. Paspatis GA, Karamanolis DG. Folate supplementation and adenomatous colonic polyps. Dis Colon Rectum. 1994;37(12): 1340-1.

79. Logan RF, Grainge MJ, Shepherd VC, Armitage NC, Muir KR. Aspirin and folic acid for the prevention of recurrent colorectal adenomas. Gastroenterology. 2008;134(1):29-38.

80. Jaszewski R, Misra S, Tobi M, Ullah N, Naumoff JA, Kucuk O, et al. Folic acid supplementation inhibits recurrence of colorectal adenomas: a randomized chemoprevention trial. World J Gastroenterol. 2008;14(28):4492-8.

81. Wu K, Platz EA, Willett WC, Fuchs CS, Selhub J, Rosner BA, et al. A randomized trial on folic acid supplementation and risk of recurrent colorectal adenoma. Am J Clin Nutr. 2009;90(6):1623-31

82. Cole BF, Baron JA, Sandler RS, Haile RW, Ahnen DJ, Bresalier RS, et al. Folic acid for the prevention of colorectal adenomas: a randomized clinical trial. JAMA. 2007;297(21):2351-9.

83. Figueiredo JC, Grau MV, Haile RW, Sandler RS, Summers RW, Bresalier RS, et al. Folic acid and risk of prostate cancer: results from a randomized clinical trial. J Natl Cancer Inst. 2009;101(6): $432-5$.

84. Figueiredo JC, Mott LA, Giovannucci E, Wu K, Cole B, Grainge MJ, et al. Folic acid and prevention of colorectal adenomas: a 
combined analysis of randomized clinical trials. Int J Cancer. 2011;129(1):192-203.

85. Vollset SE, Clarke R, Lewington S, Ebbing M, Halsey J, Lonn E, et al. Effects of folic acid supplementation on overall and sitespecific cancer incidence during the randomised trials: metaanalyses of data on 50,000 individuals. Lancet. 2013;381(9871): 1029-36. This meta-analyses of $\mathbf{1 3}$ clinical trails (10 trials with folic acid for prevention of cardiovascular disease $(n=46,969)$ and 3 trials in patients with colorectal adenomas $(n=2652)$ found a borderline $6 \%$ increase in overall cancer incidence (RR, 1.06; 95\% CI, 0.99, 1.13). However, for colorectal cancer, the risk estimate was $1.07(95 \% \mathrm{CI}, 0.83,1.37)$.

86. Ebbing M, Bonaa KH, Nygard O, Arnesen E, Ueland PM, Nordrehaug JE, et al. Cancer incidence and mortality after treatment with folic acid and vitamin B12. JAMA. 2009;302(19): 2119-26.

87. Carroll C, Cooper K, Papaioannou D, Hind D, Tappenden P, Pilgrim H, et al. Meta-analysis: folic acid in the chemoprevention of colorectal adenomas and colorectal cancer. Aliment Pharmacol Ther. 2010;31(7):708-18.

88. Wien TN, Pike E, Wisloff T, Staff A, Smeland S, Klemp M. Cancer risk with folic acid supplements: a systematic review and meta-analysis. BMJ Open. 2012;2(1), e000653. This metaanalysis of 10 clinical trials $(n=38,233)$ including 3 trials that examined the effect of folic acid supplementation on colorectal adenoma recurrence as the primary endpoint and 7 trials that examined the effect of B-vitamins on cardiovascular outcomes as the primary endpoint and cancer incidence/mortality as the secondary endpoint reported a borderline $7 \%$ increase in the incidence of cancer (RR, 1.07; 95\% CI, 1.00, 1.14).

89. Lindzon GM, Medline A, Sohn KJ, Depeint F, Croxford R, Kim YI. Effect of folic acid supplementation on the progression of colorectal aberrant crypt foci. Carcinogenesis. 2009;30(9):1536-43.

90. Song J, Medline A, Mason JB, Gallinger S, Kim YI. Effects of dietary folate on intestinal tumorigenesis in the $\mathrm{Apc}^{\mathrm{Min}}$ mouse. Cancer Res. 2000;60(19):5434-40.

91. Song J, Sohn KJ, Medline A, Ash C, Gallinger S, Kim YI. Chemopreventive effects of dietary folate on intestinal polyps in Apc+/-Msh2-/- mice. Cancer Res. 2000;60(12):3191-9.

92. Deghan Manshadi S, Ishiguro L, Sohn KJ, Medline A, Renlund R, Croxford R, et al. Folic acid supplementation promotes mammary tumor progression in a rat model. PLoS One. 2014;9(1), e84635.

93. Cravo ML, Mason JB, Dayal Y, Hutchinson M, Smith D, Selhub J, et al. Folate deficiency enhances the development of colonic neoplasia in dimethylhydrazine-treated rats. Cancer Res. 1992;52(18): 5002-6.

94. Kim YI, Salomon RN, Graeme-Cook F, Choi SW, Smith DE, Dallal GE, et al. Dietary folate protects against the development of macroscopic colonic neoplasia in a dose responsive manner in rats. Gut. 1996;39(5):732-40.

95. Ames BN. DNA damage from micronutrient deficiencies is likely to be a major cause of cancer. Mutat Res. 2001;475(1-2):7-20.

96. Choi SW, Mason JB. Folate and carcinogenesis: an integrated scheme. J Nutr. 2000;130(2):129-32.

97. Choi SW, Mason JB. Folate status: effects on pathways of colorectal carcinogenesis. J Nutr. 2002;132(8 Suppl):2413S-8S.

98. Duthie SJ. Folic acid deficiency and cancer: mechanisms of DNA instability. Br Med Bull. 1999;55(3):578-92.

99. Fenech $\mathrm{M}$. The role of folic acid and vitamin B12 in genomic stability of human cells. Mutat Res. 2001;475(1-2):57-67.

100. Lamprecht SA, Lipkin M. Chemoprevention of colon cancer by calcium, vitamin D and folate: molecular mechanisms. Nat Rev Cancer. 2003;3(8):601-14.

101. Kim YI. Folate and DNA methylation: a mechanistic link between folate deficiency and colorectal cancer? Cancer Epidemiol Biomarkers Prev. 2004;13(4):511-9.
102. Kim YI. Nutritional epigenetics: impact of folate deficiency on DNA methylation and colon cancer susceptibility. J Nutr. 2005;135(11):2703-9.

103. Crowell J, Ly A, Kim YI. Folate and DNA methylation. In: Maulik N, Maulik G, editors. Nutrition, epigenetic mechanisms, and human disease. Boca Raton: CRC Press; 2011. p. 31-75.

104. Kim YI. Will mandatory folic acid fortification prevent or promote cancer? Am J Clin Nutr. 2004;80(5):1123-8.

105. Winawer SJ, Fletcher RH, Miller L, Godlee F, Stolar MH, Mulrow $\mathrm{CD}$, et al. Colorectal cancer screening: clinical guidelines and rationale. Gastroenterology. 1997;112(2):594-642.

106. Bird RP, Good CK. The significance of aberrant crypt foci in understanding the pathogenesis of colon cancer. Toxicol Lett. 2000;112-113:395-402.

107. Mason JB. Folate consumption and cancer risk: a confirmation and some reassurance, but we're not out of the woods quite yet. Am J Clin Nutr. 2011;94(4):965-6.

108. Mason JB, Dickstein A, Jacques PF, Haggarty P, Selhub J, Dallal $\mathrm{G}$, et al. A temporal association between folic acid fortification and an increase in colorectal cancer rates may be illuminating important biological principles: a hypothesis. Cancer Epidemiol Biomarkers Prev. 2007;16(7):1325-9.

109. Hirsch S, Sanchez H, Albala C, de la Maza MP, Barrera G, Leiva $\mathrm{L}$, et al. Colon cancer in Chile before and after the start of the flour fortification program with folic acid. European Journal of Gastroenterology and Hepatology. 2009;21(4):436-9.

110. Gibson TM, Weinstein SJ, Pfeiffer RM, Hollenbeck AR, Subar AF, Schatzkin A, et al. Pre- and postfortification intake of folate and risk of colorectal cancer in a large prospective cohort study in the United States. Am J Clin Nutr. 2011;94(4):1053-62.

111. Stevens VL, McCullough ML, Sun J, Jacobs EJ, Campbell PT, Gapstur SM. High levels of folate from supplements and fortification are not associated with increased risk of colorectal cancer. Gastroenterology. 2011;141(1):98-105.

112. French AE, Grant R, Weitzman S, Ray JG, Vermeulen MJ, Sung $\mathrm{L}$, et al. Folic acid food fortification is associated with a decline in neuroblastoma. Clin Pharmacol Ther. 2003;74(3):288-94.

113. Sie KK, Li J, Ly A, Sohn KJ, Croxford R, Kim YI. Effect of maternal and postweaning folic acid supplementation on global and gene-specific DNA methylation in the liver of the rat offspring. Mol Nutr Food Res. 2013;57(4):677-85. This study demonstrates that maternal folic acid supplementation alone can influence global and gene-specific DNA methylation in rat offspring.

114. Branum AM, Bailey R, Singer BJ. Dietary supplement use and folate status during pregnancy in the United States. J Nutr. 2013;143(4):486-92.

115. Chalmers B, Dzakpasu S, Heaman M, Kaczorowski J. The Canadian maternity experiences survey: an overview of findings. J Obstet Gynaecol Can. 2008;30(3):217-28.

116. Waterland RA, Jirtle RL. Transposable elements: targets for early nutritional effects on epigenetic gene regulation. Mol Cell Biol. 2003;23(15):5293-300.

117. Wolff GL, Kodell RL, Moore SR, Cooney CA. Maternal epigenetics and methyl supplements affect agouti gene expression in Avy/a mice. FASEB J. 1998;12(11):949-57.

118. Yen TT, Gill AM, Frigeri LG, Barsh GS, Wolff GL. Obesity, diabetes, and neoplasia in yellow $\mathrm{A}(\mathrm{vy}) /$ - mice: ectopic expression of the agouti gene. FASEB J. 1994;8(8):479-88.

119. Waterland RA, Dolinoy DC, Lin JR, Smith CA, Shi X, Tahiliani KG. Maternal methyl supplements increase offspring DNA methylation at Axin Fused. Genesis. 2006;44(9):401-6.

120. Lillycrop KA, Phillips ES, Jackson AA, Hanson MA, Burdge GC. Dietary protein restriction of pregnant rats induces and folic acid supplementation prevents epigenetic modification of hepatic gene expression in the offspring. J Nutr. 2005;135(6):1382-6. 
121. Lillycrop KA, Slater-Jefferies JL, Hanson MA, Godfrey KM, Jackson AA, Burdge GC. Induction of altered epigenetic regulation of the hepatic glucocorticoid receptor in the offspring of rats fed a protein-restricted diet during pregnancy suggests that reduced DNA methyltransferase-1 expression is involved in impaired DNA methylation and changes in histone modifications. Br J Nutr. 2007;97(6):1064-73.

122. Finnell RH, Spiegelstein O, Wlodarczyk B, Triplett A, Pogribny IP, Melnyk S, et al. DNA methylation in Folbp1 knockout mice supplemented with folic acid during gestation. J Nutr. 2002;132(8 Suppl):2457S-61S.

123. Ly A, Lee H, Chen J, Sie KK, Renlund R, Medline A, et al. Effect of maternal and postweaning folic acid supplementation on mammary tumor risk in the offspring. Cancer Res. 2011;71(3):988-97.

124. Sie KK, Medline A, van Weel J, Sohn KJ, Choi SW, Croxford R, et al. Effect of maternal and postweaning folic acid supplementation on colorectal cancer risk in the offspring. Gut. 2011;60(12): 1687-94.

125. Fryer AA, Nafee TM, Ismail KM, Carroll WD, Emes RD, Farrell WE. LINE-1 DNA methylation is inversely correlated with cord plasma homocysteine in man: a preliminary study. Epigenetics. 2009;4(6):394-8.

126. Fryer AA, Emes RD, Ismail KM, Haworth KE, Mein C, Carroll WD, et al. Quantitative, high-resolution epigenetic profiling of CpG loci identifies associations with cord blood plasma homocysteine and birth weight in humans. Epigenetics. 2011;6(1):86-94.

127. Chang H, Zhang T, Zhang Z, Bao R, Fu C, Wang Z, et al. Tissuespecific distribution of aberrant DNA methylation associated with maternal low-folate status in human neural tube defects. J Nutr Biochem. 2011;22(12):1172-7.

128. Ciappio ED, Liu Z, Brooks RS, Mason JB, Bronson RT, Crott JW. Maternal B vitamin supplementation from preconception through weaning suppresses intestinal tumorigenesis in Apc $1638 \mathrm{~N}$ mouse offspring. Gut. 2011;60(12):1695-702.

129. Ciappio ED, Mason JB, Crott JW. Maternal one-carbon nutrient intake and cancer risk in offspring. Nutr Rev. 2011;69(10): $561-71$.
130. Bunin GR, Gallagher PR, Rorke-Adams LB, Robison LL, Cnaan A. Maternal supplement, micronutrient, and cured meat intake during pregnancy and risk of medulloblastoma during childhood: a children's oncology group study. Cancer Epidemiol Biomarkers Prev. 2006;15(9):1660-7.

131. Bunin GR, Kuijten RR, Buckley JD, Rorke LB, Meadows AT. Relation between maternal diet and subsequent primitive neuroectodermal brain tumors in young children. N Engl J Med. 1993;329(8):536-41.

132. Schuz J, Weihkopf T, Kaatsch P. Medication use during pregnancy and the risk of childhood cancer in the offspring. Europ J Pediatr. 2007;166(5):433-41.

133. Thompson JR, Gerald PF, Willoughby ML, Armstrong BK. Maternal folate supplementation in pregnancy and protection against acute lymphoblastic leukaemia in childhood: a case-control study. Lancet. 2001;358(9297):1935-40.

134. Orjuela MA, Titievsky L, Liu X, Ramirez-Ortiz M, PonceCastaneda V, Lecona E, et al. Fruit and vegetable intake during pregnancy and risk for development of sporadic retinoblastoma. Cancer Epidemiol Biomarkers Prev. 2005;14(6):1433-40.

135. Dockerty JD, Herbison P, Skegg DC, Elwood M. Vitamin and mineral supplements in pregnancy and the risk of childhood acute lymphoblastic leukaemia: a case-control study. BMC Public Health. 2007;7:136.

136. Milne E, Royle JA, Miller M, Bower C, de Klerk NH, Bailey HD, et al. Maternal folate and other vitamin supplementation during pregnancy and risk of acute lymphoblastic leukemia in the offspring. Int J Cancer. 2010;126(11):2690-9.

137. Lubin F, Farbstein H, Chetrit A, Farbstein M, Freedman L, Alfandary E, et al. The role of nutritional habits during gestation and child life in pediatric brain tumor etiology. Int $\mathrm{J}$ Cancer. 2000;86(1):139-43.

138. Goh YI, Bollano E, Einarson TR, Koren G. Prenatal multivitamin supplementation and rates of pediatric cancers: a meta-analysis. Clin Pharmacol Ther. 2007;81(5):685-91.

139. Obeid R, Herrmann W. The emerging role of unmetabolized folic acid in human diseases: myth or reality? Curr Drug Metab. 2012;13(8):1184-95. 